\title{
EDITORIAL
}

\section{Towards a green economy in Sri Lanka: a forestry perspective}

Sri Lanka, having been elevated to a "Middle Income Emerging Market' by the International Monetary Fund in 2010, is now pursuing to achieve even a higher level of economic growth along with enhanced human well-being. For this purpose, the development in Sri Lanka needs to be steered along an economically as well as ecologically sustainable path, incorporating the emerging ideals of a green economy advocated by the United Nations Conference on Sustainable Development held recently (Rio $+20,2012$ ). At this global summit, the UN member states including Sri Lanka, resolved to launch a process to build a green economy to achieve sustainable development goals and converge with the post-2015 development agenda. As defined by the United Nations Environment Programme (UNEP), a green economy is one that is low-carbon, resource efficient, and socially inclusive, leading to improved human well-being and social equity, significant reduction in pollution, environmental risks and ecological scarcities, and minimum loss of biodiversity and ecosystem services (UNEP, 2011).

Developing countries like Sri Lanka are facing major challenges such as increasing climate change impacts, energy insecurity and ecological scarcity. A green economy can address these challenges by opening up increasingly carbon-neutral development paths, promoting resource and energy efficiency and lessening environmental degradation. Many green sectors could provide significant opportunities for innovative research on sustainable development. Sri Lanka is a relatively small country, but with a unique ancient civilization and a proven history of sustainable development over centuries. Thus, it has the inherent potential to incorporate this traditional wisdom and indigenous knowledge with modern science to address the above challenges, while at the same time, conserving the island's richly endowed natural capital. Greening Sri Lanka's economy therefore, has the promise to be a new engine of growth, a new generation of green employment opportunities and a vital strategy to eliminate persistent poverty in a range of important sectors, viz., agriculture, forestry, fisheries, freshwater and energy.

Forests are the foundation of a green economy, pillaring much of the earth's ecological infrastructure. Forest goods and services are important components of a green economy, supporting the economic livelihoods of over one billion people globally, most of whom are in the developing countries. Natural forests of Sri Lanka, having reached a critical minimum cover, are not utilized for timber extraction anymore and therefore, needs a well-defined new direction. They still produce important non-wood forest products (NWFPs) that make a significant contribution to local economies and livelihoods by provisioning food, medicinal and/or health-care resources, which lately are emerging as export commodities. These forests being a key component of our natural capital, also make a vital contribution to ecological service infrastructure (carbon sequestration, biodiversity, water and soil conservation, pollination etc.) and in no small measure, to nature-based tourism, for which Sri Lanka has already gained global recognition (MA, 2005). Therefore, the forestry sector of Sri Lanka ought to take a lead role in greening the country's economy.

The continuing loss of forests to competing ill-planned development projects ignoring ecological consequences is the result of policy and governance failures that render forest degradation and eventual deforestation in Sri Lanka. These are compounded by market failures, as not all vital ecosystem services that natural forests sustainably provide are captured in markets. Hence they are not included in the national accounting systems, thus risking future investments in green economic initiatives.

At a global scale, there is a significant paradigm shift to include ecosystem goods and environmental/ 
ecological services into national accounting systems. At the 2010 Biodiversity Summit held in Nagoya, Japan, 193 countries agreed to incorporate the economic value of natural capital into their national accounting and reporting systems by 2020 . The Rio+20 Agreement advocates taking steps to go beyond classical gross domestic product (GDP) to assess the well-being of a country. Instead, it proposes valuing the contribution of ecosystems to human well-being through economic, ecological and social (triple bottom line) accounting, such as Green GDP (Boyd, 2007). Several international follow-up initiatives call for national accounts to be upgraded to incorporate ecosystem service values into mainstream development planning and national accounting (TEEB, 2010; SEEA, 2012; WAVES 2013, Trucost, 2013).

Taking all these emerging scenarios into account, there are both challenges and opportunities for greening the forestry sector further in Sri Lanka. This could be done by moving towards; i) re-establishment of connectivity among the remaining fragmented protected areas, through forest restoration to improve and sustain the quality of its natural forest capital, ii) establishment of economically and ecologically sustainable forest management criteria and indicators based on green economic criteria for certification (including forest plantations, mixed forest gardens and agroforestry systems), iii) reducing emissions from forest degradation and deforestation plus conservation, sustainable management of forests and enhancement of forest carbon stocks (REDD+), iv) capturing the real contributions of forests in national accounting systems, and v) examining the feasibility of initiating schemes such as 'payments for ecosystem services' (PES).

It is a challenge that Sri Lanka faces, at this crucial phase of rapid development set out in the National Physical Plan 2011-2030 (Anon, 2010), to engage in an emerging global initiative to drive towards a green economy. Nonetheless, it opens up many opportunities both for research and development to be aligned and repositioned with the evolving global scenarios in the forestry as well as other sectors, so that visionary planning now would avoid even more costly remedial measures in the future. Sri Lanka is richly endowed with a religio-cultural heritage that is inextricably linked with its equally rich natural heritage. To move towards a greener economy while learning from past experiences and judiciously blending them with innovative thinking to suit modern situations is indeed the need of the hour. We do have time-tested models for appropriately greening the forestry as well as other related sectors towards meeting our own sustainable development goals (Mori et al., 2013). The challenge now is to redefine the vision for forests of Sri Lanka in the light of emerging sustainable development goals, and to build the necessary in-country capacity to demonstrate its benefits to policymakers in our move towards a greener economy.

\section{REFERENCES}

1. Anon. (2010). National Physical Planning Policy and Plan, Sri Lanka 2011 -2030, pp. 104. Land Use Policy Planning Department, Ministry of Land and Land Development, Battaramulla.

2. Boyd J. (2007). Nonmarket benefits of nature: what should be counted in green GDP? Ecological Economics 61(4):716-723.

3. Millennium Ecosystem Assessment (MA) (2005). Ecosystems and Human Well-being: General Synthesis, pp. 137. Island Press, Washington DC, USA.

4. Mori H., Lahoti S., Saito O., Mahalingam A., Gunatilleke N., Irham Hoang V., Hitinayake G., Takeuchi K. and Herath S. (2013). Assessment of ecosystem services in home garden systems in Indonesia, Sri Lanka and Vietnam. Ecosystem Services 5: 124-136.

5. Rio+20 (2012). The Future We Want. Outcome document adapted at Rio +20 . The United Nations, New York, USA. Available at www.un.org/futurewewant

6. System of Environmental-Economic Accounting (SEEA) (2012). System of Environmental-Economic Accounting 2012: Central Framework, pp.295. United Nations, New York, USA. Available at http://unstats.un.org/unsd/ envaccounting/White_cover.pdf.

7. The Economics of Ecosystems and Biodiversity (TEEB) (2010). TEEB Report for Business - Executive Summary 2010. United Nations Environment Programme TEEB Office, Geneva, Switzerland.

8. Trucost PLC (2013). Natural Capital at Risk - The Top 100 Externalities for Business. Available at www.teebforbusiness.org.

9. United Nations Environment Programme (UNEP) (2011). Towards a green economy: pathways to sustainable development and poverty eradication - a synthesis for policy makers, pp. 45. United Nations Environment Programme, Nairobi, Kenya. Available at www.unep.org/greeneconomy.

10. Wealth Accounting and the Valuation of Ecosystem Services (WAVES) (2013). WAVES Annual Report 2013. Available at www.wavespartnership.org/waves/

Nimal Gunatilleke 